\title{
Investigation of The Relationships Between Lifelong Learning And Social Emotional Learning
}

\author{
Mehmet AKCAALAN ${ }^{1}$
}

\begin{tabular}{l} 
ARTICLE INFO \\
\hline Article History: \\
Received 08.10.2015 \\
Received in revised form \\
20.10 .2015 \\
Accepted 30.11 .2015 \\
Available online 01.01 .2016
\end{tabular}

ABSTRACT

The current research aims to investigate the relationship between lifelong learning and social emotional learning. Study group consists of 590 university students (390 females, 200 males) studying in different undergraduate programs in University of Sakarya, Faculty of Education in the Fall Term of 2015.In this research, relationships between the variables of lifelong learning and social emotional learning were investigated. Pearson Product Moment Correlation, Partial Correlation methods were utilized so as to investigate these relationships. As consequence of the research, lifelong learning and social emotional learning scores were correlating significantly. According to these results, it can be discussed that social emotional learning which can be explained as the behavioural reflection of social and emotional skills in a systematically and consistent way, has a positive relationship with lifelong learning which can be defined as all kinds of learning including formal or informal through one's life. Results are discussed within the context of the associated literature.

(C) 2016 IJERE. All rights reserved

Keywords:

Lifelong Learning, Social Emotional Learning, Demographic Variables.

\section{INTRODUCTION}

Learning is an activity to create one's experiences and to convert the experiences into information, skills, attitudes, beliefs, values, emotions and feelings, and a process of entegrating the conslusions of this to one's life (Jarvis, 2004). Learning may happen in any time or place, besides being an activity as one's conducting oneself. Learning may occur occasionally during a purposeful activity or be a planned and intentional action (Apps, 1979; Tremlett, 1999). In today's world, new information explosions impose lifelong learning to individuals to be up-to-date in their education or professions. Being a lifelong learner as well as being reformist, innovative and competitive is an experience dwelled by each person from every occupation or education level (Dunlap; 1996). All learning types of an individual so as to develop one's information, skills and competence in terms of personal, civic, social and employment are identified as lifelong learning (European Commission, 2002; Leone, 2013). Lifelong learning is an education concept which is quite popular in western countries and applied by both national and international organisations. Therefore, lifelong learning skills, attitudes and the education system itself provide a way to keep up with the speed of modern transformation (Murphy, 1999). Social emotional learning which is investigated in terms of the relationship with lifelong learning comprises of the systematical depelopment of the skills helps the individual to be able to use these skills in both social and learning environment (Ragozzino ve Utne O'Brien, 2009; Brian ve Sabina, 2013). Social and emotional learning is identified as a process of gaining necessary information, skills, attitudes and beliefs to be able to identify and manage emotions, care about someone else, making sensible decisions, behave ethically and responsibly, maintain positive relationships and avoid negative behaviours (CASEL, 2003; Elias ve diğerleri, 1997). Arslan (2015) found that the relationships between social emotional learning and educational stress were negatively associated and correlation analysis showed that sub scales of educational stress pressure from study, workload, worry about grades, self-expectation, and despondency related negatively associated with social emotional learning. Jarvis (2006) stated that the

${ }^{1}$ Corresponding e-mail: mehmetakcaalan@gmail.com

Republic of Turkey Ministry of National Education 
expression of "lifelong learning" is widely utilized to identify the intentional activities of individuals who have the intention of increasing one's information level, developing and updating skills and changing the attitudes about their lifespan. Besides, lifelong learning includes adult education, independent learning, agricultural education, business and labour force education programmes, parent education, post secondary education, pre retirement and post retirement education, remedial education, professional education but it is not limited to these education types (Apps, 1979). Application and development of formal and informal educational facilities and educational activities both inside and outside of traditional educational activities are in the scope of lifelong learning. In this context, although there is a lack of consensus about what lifelong learning exactly represents, there is a widely appreciated reconciliation that lifelong learning includes multible learning models wihch lasts during one's lifespan (Abukari, 2005; Bolhuis, 2003; Bryce, 2004; Candy, 2000; Deakin Crick, Broadfoot ve Claxton, 2004; Friesen ve Anderson, 2004; Hager, 2004; Livingstone, 2001; Smith ve Spurling, 2001; Tuijnman, 2003). The context of lifelong learning may vary widely in terms of time, place and individuals as expressed beforehand (Trudel, Callary, and Werthner, 2011). In this context, an explanation demonstrating time and learning concept spontaneously is given in Handbook of Pulman Principles (2002). According to Pulman (2002), lifelong learning is a cycle which starts early ages and continues through adulthood and a process including all the stages of formal and distance education regardless of any kind of certification. According to Sutherland, lifelong learning is explained as infinity in learning (Rogers, 2006). Social and emotional learning structure covers the definitions of non-academic or human skills which aim to provide individual's psychological happiness and social functions (Goleman, 1995; Trina, 1998). Social and emotional learning includes the competencies of capability in utilizing some actions and behaviours of some social tasks and positive development processes (Haggerty, Sherrod, Garmezy ve Rutter, 1994; Trina, 1998). Identifiying and managing feelings, self management, being empathetic to others, management of relationships, solving interpersonal conflicts and social problems are the skills of social and emotional learning (Trina, 1998). Social and emotional learning comprises of systematical and consistent teaching of social and emotional learning skills to children and teenagers. Another purpose of social and emotional learning is to promote one's goodness and avoid one's possible health problems (Greenberg, O'Brien, Weissberg ve diğerleri, 2003; Whitcomb, 2009). Social and emotional learning is a process that childen and adults improve necessary skills, attitudes and values to gain social and emotional competencies (Elias ve diğerleri, 1997; Strum, 2001). According to another alternative description, this structure is a process of getting basic competencies so as to identify and manage feelings, set and reach positive goals, care about others' thoughts, establish and maintain positive relationships, make responsible decisions, and maintain interpersonal relations (Durlak ve diğerleri, 2011; Young, 2014). Individual's comprehending, managing and explaining life tasks of their social and emotional aspects means that they can utilize skills such as learning, setting relations and solving everyday problems (Elias ve diğerleri, 1997; Strum, 2001). According to Collaborative for Academic Social and Emotional Learning (CASEL), social and emotional learning comprises of improving social and emotional learning competencies (CASEL, 2005; Long ve diğerleri, 2015). CASEL identified five social and emotional learning elements in terms of cognition, effect and behaviour competencies (CASEL, 2005; Pikul, 2015):

- Self awareness: Ability to identify definitively one's feelings, thoughts and effects of behaviours.

- Self management: Ability to regulate effectively one's feelings, thoughts and behaviours in different situations

- Social awareness: Ability to take other's perspective and empathize with them so as to understand social norms of behaviours and define family, school and community.

- Relationship skills: Ability to set and maintain healthy and valuable relationships.

- Responsible decision making: Ability to make constructive and respective choices in terms of personal behaviour and social interactions. 


\section{METHOD}

In this research, relationship between lifelong learning and social emotional learning was investigated by the help of some statistical methods. Sampling method of this investigation is specified as " convenience sampling" because of the fact that it is the most appropriate sampling method in terms of reaching to the necessary participants (Büyüköztürk, Kılıç, Çakmak, Akgün, Karadeniz ve Demirel, 2009). In 2014-2015 education term, 200 males and 390 females (590 participants) participants from different undergraduate programs of Sakarya University Education Faculty were included in this research. Demographic features of the participants are demonstrated in Table 1.

Table 1. Demographic Features of Participants

\begin{tabular}{lcc}
\hline Variable & Number & Percent \\
\hline Gender & 200 & \\
Male & 390 & 34.0 \\
Female & & 65.9 \\
\hline Age & 472 & 80.0 \\
18-21 & 105 & 17.7 \\
$22-25$ & 13 & 2.2 \\
$26-36$ & 184 & 31.1 \\
\hline Level of Grade & 240 & 40.6 \\
1.grade & 99 & 16.7 \\
2.grade & 67 & 11.3 \\
3.grade & 590 & 100 \\
4.grade & & (13 \\
Total & & \\
\hline
\end{tabular}

In this investigation, Lifelong Learning Scale (2015) which was adapted to Turkish by Arslan and Akcaalan was used to determine the participants' lifelong learning level. Moreover, Social and Emotional Learning Scale (2013) which was adapted to Turkish by Arslan and Akın was used to determine the participants's social and emotional learning level. The relationship between lifelong learning and social and emotional learning is examined in this research. SPSS 22.00 statistical package program was utilized in each stages of the data related to the research. Pearson Product Moment Correlation method was used to investigate the relationship between these variables.

\section{FINDINGS}

Detailed findings and comments of statistical analyses related to the relationship between lifelong learning and social and emotional learning are presented in this part of the investigation. Relationship between lifelong learning and social and emotional learning levels of university students and, Pearson Product Moment Correlation analyse results to determine the magnitude and directions of the relationship were demonstrated in Table 2. 
Table 2. Corelation Analyse Results of Relationship between Lifelong Learning and Social and Emotional Learning Levels of University Students

\begin{tabular}{|c|c|c|c|c|}
\hline & LLL & TD & PR & SR \\
\hline 1. LLL & 1 & & & \\
\hline 2. TD & $.49 * *$ & 1 & & \\
\hline 3. $P R$ & $.42 * *$ & $.54^{* *}$ & 1 & \\
\hline 4. SR & $.46^{* *}$ & $.60 * *$ & $.56 * *$ & 1 \\
\hline Mean & 43.53 & 22.78 & 27.98 & 27.66 \\
\hline $\begin{array}{l}\text { Standard } \\
\text { Deviation }\end{array}$ & 5.62 & 3.64 & 4.47 & 4.01 \\
\hline $\begin{array}{r}\text { Not: LLL= } \\
\text { Relationship Lev } \\
* * p<.001\end{array}$ & $\begin{array}{l}\text { Learn } \\
\text { Regul }\end{array}$ & $\begin{array}{l}\text { evel, } \\
\text { Level. }\end{array}$ & ask $\mathrm{De}$ & ion Level, $\mathrm{PR}=$ Peer \\
\hline
\end{tabular}

Table 2 demonstrates that there is significant relationship between participants' lifelong learning level and sub dimensions of social and emotional learning level; task description, peer relationship and self regulation. According to the Table 2, there is a positive direction relationship between lifelong learning and task description $(r=.49, p<.001)$, peer relationship $(r=.42, p<.001)$ and self regulation $(r=.46, p<.001)$.

\section{CONCLUSION}

The main problem of the research was to investigate if there is any the relationship between lifelong learning and social and emotional learning levels of university students. It is aimed to determine the relationship between lifelong learning and social emotional learning of individuals. There has not been any investigation found in the related literature examining the relationship between lifelong learning and social emotional learning. In this context, the relationship between lifelong learning and sub dimensions of social emotional learning -task description, peer relationships and self regulation- was examined. Positive relationship between lifelong learning and task description, peer relationships and self regulation sub dimensions of social emotional learning in university students was determined and demonstrated in Table 2. According to these findings, it can be claimed that lifelong learning which is taken into consideration as formal or informal learning embracing all life of individual is in theoretically significant relationship with social and emotional learning. Task description sub dimension is relatively in higher relationship with lifelong learning. Therefore, development in social and emotional learning field may contribute lifelong learning level. The current research was applied by the participation of the students who studied in Sakarya University Educational Faculty. That the following investigations' application with the people who are in various growth processes may be beneficial in terms of generalizability of the results. Moreover, the relationship between lifelong learning and social emotional learning may be examined involving different variables. Experimental and qualitative investigations of the relationship between lifelong learning and social emotional learning may contribute seriously to understand the relation of these variables. 


\section{REFERENCES}

Abukari, A. (2005). Conceptualizing lifelong learning: A reflection on lifelong learning at Lund University (Sweden) And Middlesex University (Uk). European Journal Of Education, 40(2), 143-154.

Apps, J. W. (1979). Problems in continuing education. Mcgraw-Hill. New York.

Arslan, S. (2015). Social emotional learning and educational stress: A Predictive model. Educational Research and Reviews, 10 (1) 184-190.

Arslan, S., Akcaalan, M. (2015). The adaptation and validation of the Turkish version of the lifelong learning scale (Lls). The Journal Of International Educational Science, Issue:4, 449-455.

Arslan, S. And Akın, A. (2013).Social emotional learning scale the study of validity and reliability.Sakarya Üniversitesi Eğitim Fakültesi Dergisi, (25).

Bolhuis, S.(2003).Towards process-oriented teaching for self-directed lifelong learning:A multidimensional perspective. Learning And Instruction, 13, 327-347.

Brian H. Smith And Sabina Low (2013) The role of social-emotional learning in bullying prevention Efforts, Theory Into Practice, 52:4, 280-287, Doi: 10.1080/00405841.2013.829731.

Bryce, J. (2004). Different ways that secondary schools orient to lifelong learning. Educational Studies, 30(1), 53-64.

Büyüköztürk, Ş., Kılıç Çakmak, E., Akgün, Ö. E., Karadeniz, Ş. Ve Demirel, F. (2009). Bilimsel araştırma yöntemleri. Ankara: Pegem Akademi Yayınları.

Candy, P. C. (2000). Reaffirming a proud tradition: Universities and lifelong learning.Active Learning In Higher Education, 1(2), 101-125.

Collaborative For Academic Social And Emotional Learning. (2005). What Is social and emotional learning? Retrieved from http://Www.Casel.Org/Social-And Emotionallearning/.

Collaborative For Academic, Social, And Emotional Learning. (2003). Safe And Sound:An Educational Leader's Guide To Evidence-Based Social And Emotional Learning (Sel) Programs. Chicago,Il.

Coryn, C. L., Spybrook, J. K., Evergreen, S. D., And Blinkiewicz, M. (2009).Development and evaluation of the social-emotional learning scale. Journal Of Psychoeducational Assessment.

Deakin Crick, R., Broadfoot, P., And Claxton, G. (2004). Developing an effective lifelong learning inventory: The elli project. Assessment In Education, 11(3),247-272.

Dunlap, J. C. (1996). The relationship of problem-based learning to life-long learning.University of Colorado Denver.

Durlak, J. A., Weissberg, R. P., Dymnicki, A. B., Taylor, R. D., And Schellinger, K. B. (2011). The impact of enhancing students' social and emotional learning:A meta-analysis of school-based üniversal interventions.Child Development,82(1), 405-432.

Elias, Maurice J., Joseph E. Zins, Roger P. Weissberg, Karin S. Frey, Mark T. Greenberg, Norris M. H., Rachael K., Mary E.,Schwab S., And Timothy P. S., (1997). Promoting social and emotional learning: Guidelines For Educators. Alexandria, Va: Association For Supervision And Curriculum Development.

European Commission.(2002).European Report on quality indicators of ifelong Learning.Brussels:European Commission.

Friesen, N., And Anderson, T. (2004). Interaction for lifelong learning. British Journal Of Educational Technology, 35(6), 679-687. 
Goleman, D. (1995). Emotional intelligence. why it can matter more than Iq.

Learning, 24(6), 49-50.

Greenberg, M. T., Weissberg, R. P., Utne O'brien, M. T., Zins, J. E., Fredericks, L., Resnik, H. and others (2003). Enhancing school-based prevention and youth development through coordinated social, emotional, and academic learning. American Psychologist, 58, 466-474.

Hager, P. (2004). Lifelong learning in the workplace?Challenges and issues.Journal Of Workplace Learning, $16(1 / 2), \quad 22-32$.

Haggerty, R. J., Sherrod, L. R., Garmezy, N., And Rutter, M. (1994). Stress, risk, and resilience in children and adolescents:Processes, mechanisms, and interventions. Cambridge:Cambridge University Press.

Jarvis, P. (2004). Adult education and lifelong learning: Theory and practice. Routledge, Routledgefalmer, New York.

Jarvis, P. (2006). Towards a comprehensive theory of human learning: Lifelong learning and the learning society. Vol. 1. New York: Routledge.

Kirby, J. R., Knapper, C., Lamon, P., And Egnatoff, W. J. (2010). Development of a scale to measure lifelong Learning. International Journal Of Lifelong Education, 29(3), 291-302.

Leone, S. (2013). Characterisation of a personal learning environment as A lifelong learning tool. Springer Science And Business Media.

Livingstone, D. W. (2001). Adults' informal learning: Definitions, Findings, gaps, and future research. Ontario Inst. For Studies In Education, Toronto.

Long, K., Brown, J. L., Jones, S. M., Aber, J. L., And Yates, B. T.(2015) Cost analysis of a school-based social and emotional learning and literacy intervention. Journal Of Benefit-Cost Analysis, 1-27.

Murphy, T. F. M., (1999). Power and knowledge in education: A critical exploration oflifelong learning. Doctoral Dissertation.Northern Illinois University, Illinois.

Pikul, M. A. (2015). Changes in the social and emotional wellness of students after participation in a mentoring program, Doctoral Dissertation, Concordia University.

Pulman. (2002). Public libraries mobilising advanced networks. Handbook Retrieved September 18, 2013 From: http://www.kutuphaneci.org.tr/genel/pilkeler.pd.

Ragozzino, K. and O’Brien, M. U. (2009). Social and emotional learning and bullying prevention. Collaborative For Academic, Social, And Emotional Learning, Chicago, IL.

Rogers, A. (2006). Learning: Concepts and contexts in international journal of educational development, Science Direct 28 (1) 110-111.

Smith, J., And Spurling, A. (2001). Understanding motivation for lifelong learning. National Institute Of Adult Continuing Education, Renaissance House.

Strum, J. R. (2001). An action research study of a social-emotional learning program and its effect on the behavior and academic success of fifth grade students. Thesis, University Of California.

Tremlett, L. (1999). An investigation of lifelong learning in the context of traditional educational policy and practice. University Of Toronto.

Trina, E. (1998). Social-emotıonal learning in the elementary classroom: An inquiry into the needs of teachers

and subsequent training program development. Doctor Of Psychology. The State University Of New Jersey.

Trudel, P., Callary, B., And Werthner, P., (2011). Shaping the way five women coaches develop: Their primary and secondary socialization. Journal Of Coaching Education, 4(3), 76-125. 
Tuijnman, A. (2003). Measuring lifelong learning for the new economy. Compare, 33(4), 471-482.

Whitcomb,S.A.(2009). Strong start: impact of direct teaching of a social-emotional learning curriculum and infusion of skills on emotion knowledge of first grade students Doctoral Dissertation,University Of Oregon,Oregon.

Young,J.L.(2014). Evaluating the effectiveness of positive life changes social emotional learning curriculum.Doctora Dissertation, University Of Minnesota, Minnesota. 